\title{
WYKŁADNIA PRAWA JAKO DZIAŁANIE OPTYMALIZACYJNE
}

\begin{abstract}
Abstrakt: Głównym celem artykułu jest udowodnienie tytułowej tezy, zgodnie z którą interpretacja prawnicza może być postrzegana jako działanie optymalizacyjne, ponieważ jest to działanie, które nieuchronnie zmierza do maksymalizacji wartości przedmiotu interpretacji (tekstu prawnego). Ponadto, pragnę wykazać, że zarówno interpretacja prawnicza, jak i interpretacja filozoficzna mają wspólne cechy, takie jak intuicyjność, przez którą rozumiem niemożliwość stosowania empirycznych kryteriów prawomocności formułowanych twierdzeń. Zarówno w przypadku interpretacji prawa, jak i poznania filozoficznego interpretacja pełni funkcję optymalizacyjną, przez którą rozumiem ujawnianie aksjologicznego ładu w przedmiocie poznania.
\end{abstract}

Słowa kluczowe: wykładnia prawa, działanie optymalizacyjne, maksymalizacja wartości, poznanie prawnicze, poznanie filozoficzne

Podstawową tezą opracowania jest twierdzenie, że wykładnia prawa jest typem aktywności sensotwórczej, która optymalizuje przedmiot interpretacji (tekst prawny) w ten sposób, że jest działaniem maksymalizującym wartość tekstu prawnego. Taki charakter ma wykładnia zarówno w koncepcjach analitycznych, jak i hermeneutycznych interpretacji prawniczej ${ }^{1}$. Ze względu na przyjęte ramy opracowania ograniczam się do wykazania trafności tej tezy w odniesieniu do teorii analitycznych. Analityczne koncepcje wykładni prawa traktują interpretację jako sposób ustalania znaczenia tekstu prawnego na podstawie analizy logiczno-semiotycznej języka prawnego i prawniczego. Przedmiotem analitycznych ujęć wykładni prawa jest także logiczno-semiotyczna analiza decyzji interpretacyjnych (twierdzeń interpretacyjnych), ze szczególnym uwzględnieniem ich statusu semantycznego oraz kryteriów prawomocności.

${ }^{1}$ Por. K. Opałek, J. Wróblewski, Prawo, metodologia, filozofia, teoria prawa, Warszawa 1991, s. 262-273. 
W reprezentatywnej dla nurtu analitycznego klaryfikacyjnej teorii wykładni Jerzego Wróblewskiego wykładnia jest postrzegana jako sposób ustalania znaczenia tekstu prawnego w tak zwanej sytuacji wykładni, to znaczy gdy tego nie da się ustalić w bezpośrednim rozumieniu tekstu prawnego, pojmowanego jako intuicyjne zastosowanie reguł sensu języka, w którym sformułowane są teksty prawne. Podstawowa w tej teorii wykładni zasada clara non sunt interpretanda zakłada, że wykładnia jest zbędna, jeżeli w następstwie bezpośredniego rozumienia tekstu prawnego podmiot stosujący prawo jest w stanie osiągnąc poziom pragmatycznie pojmowanej jasności wystarczający do rozstrzygnięcia konkretnego przypadku. W trudnych przypadkach, w których bezpośrednie rozumienie tekstu prawnego jest niewystarczające do osiągnięcia pojmowanej pragmatycznie jasności, konieczne jest pośrednie rozumienie tekstu, a więc jego wykładnia, polegająca na zastosowaniu dyrektyw interpretacyjnych. Kluczowe dla tej koncepcji pragmatyczne ujęcie jasności tekstu prawnego zakłada, że poziom jasności lub niejasności danego tekstu powinien być zawsze oceniany w kontekście konkretnego stanu faktycznego, będącego przedmiotem rozstrzygnięcia. Oznacza to, że ten sam fragment tekstu, który jest jasny w sytuacji S1, może być niejasny w sytuacji S2.

W omawianej koncepcji znaczeniem tekstu (normy prawnej) jest wzór zachowania $^{2}$. Struktura wzoru zachowania jest wyznaczona strukturą normy i obejmuje określenie adresata, okoliczności oraz zachowanie, które jest nakazane, zakazane lub dozwolone. Traktując wzór zachowania jako pewien konstrukt pojęciowy, możemy powiedzieć, że w omawianej koncepcji znaczenie normy jest określone w sposób intensjonalny. Tak pojmowany wzór zachowania odnosi się do rzeczywistości pozajęzykowej w ten sposób, że oznacza zjawiska występujące w tej rzeczywistości, dzieląc je na te, które należą do zakresu stosowania normy, to znaczy przez zgodność lub niezgodność z wzorem zachowania wywołują określone w normie skutki prawne, oraz te, które nie należą do zakresu stosowania normy, czyli mówiąc inaczej, są prawnie indyferentne ${ }^{3}$. Określone w wyniku wykładni twierdzenie interpretacyjne ma postać: „Norma $\mathrm{N}$ ma znaczenie $\mathrm{Z}$ na podstawie dyrektyw interpretacyjnych D1, D2, Dn oraz wartości (ocen) W1, W2, Wn"4. Ze względu na poziom uwikłania aksjologicznego twierdzenie odpowiadające takiej formule nie jest zdaniem w sensie logicznym. Oznacza to, że wypowiedź odpowiadająca formule twierdzenia interpretacyjnego nie jest prawdziwą lub fałszywą wypowiedzią wyposażoną w jednoznaczny sens deskryptywny. Jest tak, mimo

2 Por. J. Wróblewski, Zagadnienia teorii wyktadni prawa ludowego, Warszawa 1959, s. 74 n.

${ }^{3}$ Por. J. Wróblewski, Zwroty stosunkowe - wypowiedzi o zgodności z norma, „Zeszyty Naukowe Uniwersytetu Łódzkiego. Nauki humanistyczno-społeczne, seria I" 1969, nr 62, passim.

${ }^{4}$ J. Wróblewski, Rozumienie prawa i jego wyktadnia, Wrocław 1990, s. 88-93; por. teżZ. Pulka, Przesłanki prawomocności decyzji interpretacyjnej w teorii wykładni Jerzego Wróblewskiego, „Przegląd Prawa i Administracji” 100/2, 2015. 
że autor posługuje się pojęciem „rzeczywistego znaczenia normy” oraz mimo uznania, że znaczenie normy jest zawsze, przynajmniej w pewnym stopniu, niezależne od interpretatora i w tym sensie istnieje obiektywnie ${ }^{5}$. Wydaje się, że autor zakłada, iż odpowiadające tej formule twierdzenie interpretacyjne legitymuje się prawomocnością o charakterze argumentacyjnym, w którym prawomocność twierdzenia jest synonimem jego akceptowalności w następstwie zastosowanych zabiegów argumentacyjnych. Oznacza to, że twierdzenie interpretacyjne jest prawomocne, czyli akceptowalne, w następstwie akceptacji zastosowanych dyrektyw interpretacyjnych oraz ocen, których przyjęcie zakłada posłużenie się przez interpretatora określonymi dyrektywami interpretacyjnymi. Jakkolwiek autor uznaje, że dyrektywy interpretacyjne mogą pełnić zarówno funkcję heurystyczną, jak i uzasadniającą, to jednak wydaje się, że w omawianej teorii wykładni dyrektywy interpretacyjne wraz z towarzyszącymi ich zastosowaniu ocenami pełnią głównie funkcję uzasadnienia przyjętego przez interpretatora rozstrzygnięcia interpretacyjnego. Określenie takiego uzasadnienia jest podstawowym elementem argumentacji stosowanej w dyskursie interpretacyjnym.

Występujące we wszystkich fazach rozwoju omawianej teorii wykładni prawa założenie o istnieniu obiektywnego znaczenia normy oznacza, że jest ono przynajmniej w standardowych przypadkach - w znacznej mierze wyznaczone przez prawodawcę. Zadaniem interpretatora nie jest zatem kreacja znaczenia normy, lecz tylko jego optymalizująca rekonstrukcja w następstwie logiczno-semiotycznej analizy tekstu prawnego. Jest to teza zgodna z przyjętymi przez autora założeniami ideologicznymi, określonymi w postaci ,ideologii praworządnej i racjonalnej decyzji sądowej"

W klaryfikacyjnej koncepcji wykładni wykładnia jest działaniem optymalizacyjnym ze względu na kluczowe dla tej koncepcji założenie systemowości prawa $^{7}$. Warto zwrócić uwagę, że w koncepcji klaryfikacyjnej systemowość prawa jest przesądzona na poziomie pierwotnych poznawczo założeń filozoficznych. Zgodnie z nimi „prawo ludowe” jest narzędziem globalnej przebudowy społecznej prowadzącej do osiągnięcia bytu wyższego rzędu (byt wolny od alienacji), który jest celem historii określonym przez logos (rozum) dziejowy ${ }^{8}$. Na tym polegać ma jedność teleologiczna „prawa ludowego” jako skutecznego środka realizacji ostatecznego celu historii, wyznaczonego przez rozum dziejowy. „Prawo ludowe”

5 J. Wróblewski, Zagadnienia teorii..., s. 189 n., 408 n.; por. idem, Rozumienie prawa..., passim.

${ }^{6}$ J. Wróblewski, Sądowe stosowanie prawa, Warszawa 1988, rozdz. XIV.

${ }^{7}$ Kwestię tę omawiam w następujących opracowaniach: Z. Pulka, Założenie spójności semantycznej systemu prawa w klaryfikacyjnej teorii wyktadni, [w:] Postanalityczna filozofia prawa, red. M. Paździora, „Przegląd Prawa i Administracji” 102, 2015; oraz idem, Filozoficzne przesłanki pojmowania systemowości prawa w teorii wyktadni Jerzego Wróblewskiego, [w:] Systemowość prawa, red. Z. Pulka „Przegląd Prawa i Administracji” 104, 2016.

8 Por. Z. Pulka, Przesłanki prawomocności..., s. 611 n.; idem, Filozoficzne przesłanki pojmowania..., s. $221 \mathrm{n}$. 
cechuje ponadto nie tylko jedność socjologiczna, ponieważ jako całość wyraża ono wolę klasy panującej, lecz także jedność aksjologiczna, gdyż wyraża ono spójny system wartości wewnętrznych (wartości zakodowane w prawie przez prawodawcę) $)^{9}$. Wartości te określają nową i zarazem wyższą formę życia (byt wyższego rzędu), której osiągnięciu służyć mają środki prawne. System prawa cechuje też wysoki poziom spójności formalnej, którą tworzą więzi pionowe związane z hierarchią autorytetów normodawczych, a także spójności materialnej, ponieważ przyjmuje się, że w systemie prawa normy zwykłe są treściowo zgodne z normami zasadniczymi ${ }^{10}$.

Trzeba wyraźnie podkreślić, że w teorii wykładni Jerzego Wróblewskiego systemowość jest cechą immanentną (konieczną) prawa. Prawo dane jest jako system w wyniku działań prawodawcy, a nie staje się systemem w wyniku działań interpretatora. Kategoria systemu prawa ma więc tutaj konotację wyraźnie ontologiczną, co oznacza, że system norm jest konieczną formą istnienia prawa, a więc prawo bytuje jako system norm czy też może bytować (istnieć) tylko w formie systemu norm. Kategoria systemu prawa jako kategoria ontologiczna opisuje sposób istnienia prawa, nie jest zaś jako kategoria epistemologiczna jedynie narzędziem poznania prawa. Kategoria systemu ma tutaj interpretację wyraźnie realistyczną jako kategoria opisująca realny byt prawa, a nie interpretację instrumentalną, czyli wskazującą wyłącznie na dogodny instrument służący poznaniu prawa ${ }^{11}$.

W omawianej koncepcji wykładni założenie systemowości prawa jest zatem koniecznym założeniem ontologicznym, które musi przyjąć interpretator dokonujący wykładni tekstu prawnego. Dokonując wykładni prawa czy też poznając prawo w procesie wykładni, interpretator musi przyjąć, że ma do czynienia z bytem systemowym, to znaczy istniejącym w formie systemu norm charakteryzującego się jednością teleologiczną, socjologiczną, aksjologiczną, formalną i materialną. Jak już wskazywałem, założenie tak pojmowanej systemowości prawa jest przesądzone na poziomie pierwotnych poznawczo założeń (presupozycji) filozoficznych (ontologicznych) dotyczących istnienia „prawa ludowego”, pojmowanego jako narzędzie tworzenia wyższej formy społecznego istnienia. W konsekwencji na gruncie omawianej teorii prawa formułowana jest teza, że jeżeli w systemie „prawa ludowego" występują jakieś sprzeczności, to nie są to sprzeczności realne, lecz pozorne. Sprzeczności realne są charakterystyczne dla systemów prawnych działających w warunkach bytu niższego rzędu i jako związane z konfliktem klasowym mają nie tylko charakter polityczny, lecz także są zamierzone przez prawodawcę, który w konstytucji przyznaje określone prawa podmiotowe, a w aktach niższego rzędu wyklucza ich realizację. Ponieważ w warunkach bytu wyższego rzędu,

9 Por. J. Wróblewski, Wartości a decyzja sądowa, Wrocław 1973, s. 47 n.

${ }^{10}$ Por. W. Lang, J. Wróblewski, S. Zawadzki, Teoria państwa i prawa, Warszawa 1986, rozdz. 19.

${ }^{11}$ Por. J. Wróblewski, Modele systemów norm a system prawa, „Studia Prawno-Ekonomiczne”1969, nr 2, passim; por. też idem, Decyzja sądowa a koncepcje systemu prawa, „Acta Universitatis Lodziensis. Nauki społeczno-humanistyczne, seria I” 1978, z. 28, passim. 
w którym działa „prawo ludowe”, nie występują już konflikty klasowe, oznacza to nieistnienie obiektywnych przesłanek do powstania sprzeczności realnych. W konsekwencji, jeżeli nawet w systemie prawa występują określone sprzeczności, mogą to być wyłącznie sprzeczności pozorne, które jako związane z użyciem niewłaściwych sformułowań przez prawodawcę są możliwe do usunięcia przez interpretatora $\mathrm{w}$ wykładni prawa ${ }^{12}$. Inaczej mówiąc, nie są to sprzeczności prawa związane z realnymi konfliktami politycznymi (sprzeczności polityczne) i wymagające działań legislacyjnych w celu ich usunięcia, lecz tylko sprzeczności na poziomie sformułowania prawa związane z niedoskonałościami techniki legislacyjnej (ustawodawca źle się wyraził) i możliwe do usunięcia w formie wykładni.

Na gruncie omawianej teorii wykładni, w ramach wykładni językowej, założenie systemowości prawa znajduje wyraz w formie postulatu spójności semantycznej tekstu prawnego ${ }^{13}$. Warto podkreślić, że w teorii wykładni J. Wróblewskiego za jedną z bardziej oczywistych właściwości języka prawnego uznaje się określony poziom jego spójności semantycznej, co oznacza przyjęcie założenia, że równokształtne wyrażenia w tekście prawnym mają, lub przynajmniej powinny mieć, to samo znaczenie co najmniej w ramach danego aktu prawnego lub szerzej — w ramach danej gałęzi prawa lub całego systemu prawnego. Postulat spójności semantycznej tekstu prawnego jest wyrażony w większości proponowanych przez J. Wróblewskiego dyrektyw wykładni językowej. Przykładem mogą być takie dyrektywy, jak: zakaz wykładni homonimicznej, domniemanie języka potocznego czy też domniemanie języka prawnego. Dyrektywa pierwsza zakazuje uznawania wyrażeń języka prawnego za homonimy. Z kolei wskazane domniemania zakazują przypisywania „bez dostatecznych powodów” interpretowanym zwrotom swoistego znaczenia prawnego, gdy znaczenie to jest określone przez język potoczny (domniemanie języka potocznego), lub swoistego znaczenia terminologicznego należącego do terminologii części systemu prawa (gałęzi prawa), gdy znaczenie to jest określone przez język prawny, na przykład przez definicję legalną (domniemanie języka prawnego) ${ }^{14}$. Warto podkreślić, że te dyrektywy są zaliczane przez autora do kategorii „powszechnych dyrektyw interpretacyjnych”, jako że są one wspólne zarówno dla statycznych, jak i dynamicznych ideologii wykładni. W konsekwencji ich uwzględnienie jest obowiązkiem interpretatora zmierzającego do ujawnienia „rzeczywistego znaczenia normy”. Mając to na względzie, można powiedzieć, że w omawianej teorii wykładni prawa optymalizacyjny sens

12 J. Wróblewski, Zagadnienie niesprzeczności i zupetności systemu prawa, „Zeszyty Naukowe Uniwersytetu Łódzkiego. Nauki humanistyczno-społeczne, seria I” 1958, z. 9, passim; por. też Z. Pulka, Filozoficzne przestanki pojmowania..., s. 234 n.

${ }^{13}$ Por. Z. Pulka, Założenie spójności semantycznej..., passim.

14 Por. J. Wróblewski, Zagadnienia teorii..., s. 245-246; por. też K. Opałek, J. Wróblewski, Zagadnienia teorii prawa, Warszawa 1969, s. 246-247; W. Lang, J. Wróblewski, S. Zawadzki, op. cit., s. 443. 
wykładni językowej polega na dążeniu do osiągnięcia jak największej spójności semantycznej zinterpretowanego tekstu prawnego.

Na poziomie wykładni systemowej i funkcjonalnej założenie systemowości prawa obejmuje dwie kwestie: 1. jakie są elementy systemu oraz jego zakres, 2. zagadnienie niesprzeczności i zupełności systemu prawa ${ }^{15}$. Pierwsza kwestia jest rozstrzygnięta przez przyjęcie koncepcji obowiązywania systemowego, zgodnie $\mathrm{z}$ którym norma $\mathrm{N}$ obowiązuje, jeżeli pozostaje $\mathrm{w}$ określonych relacjach do innych norm systemu prawa ${ }^{16}$. Druga kwestia jest rozstrzygnięta przez uznanie sprzeczności w tekście prawnym za sprzeczności pozorne oraz przez uznanie luk w regulacji prawnej za rodzaj sprzeczności pozornych, które polegają na sprzeczności między generalnym nakazem rozstrzygnięcia i zakazem rozstrzygnięcia wynikającym z braku lub niekompletności regulacji prawnej ${ }^{17}$. Jak już wskazywałem, pozorność tych sprzeczności zakłada, że mogą być rozstrzygnięte w wykładni, nie jest to bowiem mająca obiektywne podstawy polityczne sprzeczność norm, lecz tylko sprzeczność na poziomie sformułowania norm. System „prawa ludowego” jest zatem nie tylko realnie niesprzeczny, lecz także realnie zupełny. W tym wypadku optymalizacyjność wykładni systemowej polega zatem na usuwaniu pozornych sprzeczności zabiegami interpretacyjnymi będącymi dostatecznie pogłębioną analizą zakresów stosowania konfliktowych norm.

Z kolei na poziomie wykładni funkcjonalnej optymalizacyjność wykładni przejawia się w dążeniu interpretatora do uzyskania jak najwyższego poziomu spójności aksjologicznej systemu prawa. Na gruncie omawianej teorii wykładni nakaz uzyskania maksymalnego stopnia spójności aksjologicznej tekstu prawnego wyrażają dyrektywy nakazujące interpretatorowi zachowanie konsekwencji w posługiwaniu się nie tylko celem normy lub celem prawa (ratio legis lub ratio iuris), lecz także wartościami pozaprawnymi wyrażonymi w postaci pozaprawnych reguł społecznych, takich jak zasady współżycia społecznego czy też zasady słuszności ${ }^{18}$. Przy założeniu, że zasady prawa to normatywna postać wartości, nakaz uzyskania maksymalnego poziomu spójności aksjologicznej tekstu prawnego wyraża także dyrektywa nakazująca tak ustalać znaczenie interpretowanej reguły, aby była ona najbardziej koherentna $\mathrm{z}$ uznaną zasadą prawa ${ }^{19}$.

Ogólnie można zatem powiedzieć, że w ujęciu klaryfikacyjnej koncepcji wykładni interpretacja tekstu prawnego jest działaniem optymalizacyjnym, ponieważ ma prowadzić do maksymalizacji spójności semantycznej, formalnej i aksjologicznej systemu prawa. W omawianej teorii wykładni prawo jest systemem zarówno jako punkt wyjścia działań interpretacyjnych (system LSFC — prawo

15 Por. Z. Pulka, Filozoficzne przesłanki..., s. 229 n.

${ }^{16}$ Por. J. Wróblewski, Obowiązywanie systemowe i granice dogmatycznego podejścia do systemu prawa, „Studia Prawno-Ekonomiczne” 36, 1986, passim.

17 Por. przyp. 12.

${ }^{18}$ Por. J. Wróblewski, Zagadnienia teorii..., s. 380 n.; por. też idem, Rozumienie..., s. 85-86.

19 Por. J. Wróblewski, Rozumienie..., s. 83. 
obowiązujące obejmujące normy spełniające kryteria obowiązywania systemowego oraz formalne konsekwencje tych norm), jak i ich rezultat (system LSIC — prawo zinterpretowane $)^{20}$. Oznacza to, że celem wykładni jest osiągnięcie wyższego poziomu systemowości prawa, ponieważ jak wynika z tych ustaleń, prawo zinterpretowane, które określa model systemu LSIC, wykazywać ma wyższy poziom systemowej spójności w porównaniu z prawem stanowiącym punkt wyjścia zabiegów interpretacyjnych, które określa model systemu LSFC.

W klaryfikacyjnej teorii wykładni Jerzego Wróblewskiego kwestia, na czym polega optymalizacja prawa przez interpretatora, jest przesądzona na poziomie pierwotnych poznawczo założeń filozoficznych, instrumentalizujących „prawo ludowe" jako narzędzie globalnej przebudowy społecznej, związanej z przejściem do wyższej formy społecznego istnienia w postaci bytu wolnego od alienacji. Przy takich założeniach filozoficznych wykładnia prawa jest działaniem optymalizacyjnym, które maksymalizuje wartość prawa jako sprawnego narzędzia przebudowy społecznej, przez uzyskanie w drodze zabiegów interpretacyjnych wyższego poziomu jego systemowej spójności.

Koncepcja derywacyjna wykładni jest drugim przykładem ujęcia analitycznego interpretacji prawniczej w polskiej literaturze teoretycznoprawnej ${ }^{21}$. Jak wiadomo, koncepcja ta odrzuca możliwość ustalenia znaczenia tekstu prawnego przez jego bezpośrednie rozumienie, to znaczy bezrefleksyjne (intuicyjne) posłużenie się regułami sensu języka prawnego. Oznacza to odrzucenie reguły clara non sunt interpretanda i zastąpienie ją regułą omnia sunt interpretanda ${ }^{22}$. Dyrektywę tę należy rozumieć nie tylko jako nakaz poddania interpretacji każdego fragmentu tekstu prawnego bez względu na poziom jego intuicyjnie odczuwanej jasności, lecz także jako nakaz holistycznego ujęcia tego fragmentu tekstu prawnego, który jest przedmiotem interpretacji. Holistyczne ujęcie oznacza tu nie tylko, że będący przedmiotem interpretacji fragment tekstu (przepis prawny) powinien być poddany interpretacji w całości, czyli wszystkie wyrażenia składające się na przepis prawny powinny być przedmiotem zabiegów interpretacyjnych, lecz również dany fragment tekstu (przepis prawny) powinien być zawsze postrzegany jako integralny element tekstu prawnego pojmowanego jako ogół przepisów prawnych obowiązujących w momencie dokonywania interpretacji. Ponadto ujęcie holistyczne tekstu poddanego interpretacji zakłada, że jest on postrzegany zarówno

${ }^{20}$ Por. Z. Pulka, Filozoficzne przestanki..., s. 242-249.

${ }^{21}$ Por. przyp. 1.

22 Por. A. Chodun, Maciej Zieliński's (derivative) concept of legal interpretation, „Studia Prawa Publicznego" 2015, nr 2 (10), s. 121-124. 
w wymiarze językowym, a więc jako wypowiedź językowa będąca przedmiotem analizy logiczno-semiotycznej, jak i w wymiarze kulturowym, a więc jako przedmiot kulturowy, którego sens determinują kulturowo wykształcone wartości23.

W ujęciu derywacyjnym wykładni interpretacja przepisu prawnego oznacza czynność polegającą na zastąpieniu $\mathrm{z}$ wykorzystaniem reguł $\mathrm{R}$ przepisu prawnego $\mathrm{P}$ wyrażeniem $\mathrm{N}$ jednoznacznym z przepisem $\mathrm{P}$ (na gruncie reguł $\mathrm{R}$ ), a będącym normą postępowania. Natomiast interpretacja tekstu prawnego (zbioru przepisów) polega na zastąpieniu tekstu prawnego za pomocą reguł $\mathrm{R}$ zbiorem norm postępowania jednoznacznym na gruncie reguł $\mathrm{R} z$ tekstem prawnym ${ }^{24}$.

Zauważmy, że w kontekście omawianej koncepcji norma jest traktowana jako wypowiedź jednoznaczna lub co najmniej charakteryzująca się wyższym poziomem jednoznaczności w porównaniu z przepisem prawnym. Gdy przedmiotem wykładni jest tekst prawny (zbiór przepisów), jego interpretacja polega na przypisaniu mu znaczenia w postaci zbioru norm uporządkowanych systemowo (powiązanych relacjami formalnymi i treściowymi), który charakteryzuje określony poziom niesprzeczności i zupełności regulacji prawnej. Punktem wyjścia wykładni jest przepis lub zbiór przepisów (tekst prawny) postrzegany jako chaotyczny i alogiczny zbiór wypowiedzi niejednoznacznych, a rezultatem wykładni norma lub uporządkowany systemowo zbiór norm, postrzeganych jako wypowiedzi charakteryzujące się wysokim poziomem jednoznaczności. Zwróćmy także uwagę, że między przepisem a zrekonstruowaną na jego podstawie normą oraz między zbiorem przepisów a zrekonstruowanym na jego podstawie zbiorem norm występuje relacja jednoznaczności, która w omawianym ujęciu jest postrzegana jako relacja zastępowalności. Inaczej mówiąc, przepis i norma oraz zbiór przepisów i zbiór norm to różne formy służące wyrażeniu tej samej treści, to znaczy, że ich zawartość treściowa jest ta sama. Jednak forma norm lub zbioru norm jest nieporównanie doskonalsza niż forma przepisu lub zbioru przepisów, pod względem zarówno poziomu jednoznaczności, jak i systemowego uporządkowania.

Omawiana koncepcja wykładni zakłada pojęcie prawa, w którym prawo charakteryzuje się dualistyczną strukturą ${ }^{25}$. Prawo obejmuje bowiem dwa elementy lub też może być rozpatrywane na dwóch poziomach: 1. przepis lub zbiór przepisów (tekst prawny), który tworzy dostępną obserwacji (postrzeganiu) strukturę powierzchniową prawa, oraz 2. norma lub zbiór norm tworzących poznawaną w procesie interpretacji strukturę głęboką prawa. Między tymi elementami występuje relacja jednoznaczności (relacja zastępowalności). Interpretacja jest procesem przejścia od jednego poziomu do drugiego, obejmującym fazy porządkującą, rekonstrukcyjną i percepcyjną. W tym przejściu od poziomu deskryptywnego tekstu (poziom przepisów) do poziomu dyrektywalnego tekstu (poziom norm) upa-

${ }^{23}$ Ibidem, s. 122.

${ }^{24}$ Por. M. Zieliński, Interpretacja jako proces dekodowania tekstu prawnego, Poznań 1972, s. 27.

${ }^{25}$ Por. W. Patryas, Rozważania o normach prawnych, Poznań 2001, passim. 
trywana jest osobliwość interpretacji prawniczej w porównaniu z innymi typami interpretacji tekstu, na przykład interpretacją literacką ${ }^{26}$. W koncepcji derywacyjnej interpretacja tekstu prawnego jest zatem postrzegana w perspektywie epistemologicznej jako proces poznania struktury głębokiej prawa, którą prawodawca zakodował w postaci przepisów prawnych tworzących strukturę powierzchniową tekstu prawnego. Celem wykładni jest więc ujawnienie struktury głębokiej prawa, zakodowanej w strukturze powierzchniowej przez prawodawcę ${ }^{27}$. Istotne jest założenie, że struktura powierzchniowa jest konieczną ze względu na wymogi techniki legislacyjnej formą przejawiania się struktury głębokiej prawa. Interpretator nie tworzy więc struktury głębokiej prawa, lecz tylko ją ujawnia czy też poznaje przez dokonywane zabiegi interpretacyjne.

Koncepcja derywacyjna eksponuje systemowość prawa. W ujęciu derywacyjnym interpretacja przepisu właściwie zawsze zakłada interpretację tekstu prawnego (zbioru przepisów) ${ }^{28}$. W fazie porządkującej, ustalając aktualne brzmienie tekstu prawnego, należy zidentyfikować przepisy derogacyjne i nowelizujące. W fazie rekonstrukcyjnej, dokonując przejścia z poziomu deskryptywnego na poziom dyrektywalny przez rekonstrukcję wyrażenia normokształtnego, należy zidentyfikować przepisy uzupełniające przepis zrębowy (przepis określający zachowanie nakazane lub zakazane) oraz przepisy modyfikujące przepis centralny (przepis zrębowy zupełny syntaktycznie, to znaczy zawierający wszystkie elementy normy zawarte w przepisie zrębowym oraz przepisach uzupełniających określających adresata i okoliczności tworzące hipotezę normy) ${ }^{29}$. Warto podkreślić, że w fazie rekonstrukcyjnej interpretator powinien poszukiwać przepisów modyfikujących w odniesieniu do wszystkich elementów tworzących przepis centralny. W fazie tej interpretowany przepis jest zatem zawsze postrzegany jako element tekstu prawnego, w którym oprócz przepisów zrębowych występują przepisy uzupełniające przepis zrębowy oraz przepisy modyfikujące przepis centralny ${ }^{30}$. Interpretowany przepis jest więc zawsze postrzegany jako element tekstu prawnego obejmującego zbiór wszystkich przepisów obowiązujących w momencie interpretacyjnym.

W fazie percepcyjnej wykładni wspomniane ujęcie holistyczne przejawia się w formie dyrektywy zupełności wykładni. Dyrektywa ta wymaga, aby w odniesieniu do każdego terminu wchodzącego w skład wyrażenia normokształtnego przeprowadzić pełny repertuar zabiegów klaryfikacyjnych polegających na zastosowaniu dyrektyw wykładni językowej, systemowej i funkcjonalnej. Celem fazy percepcyjnej jest bowiem uzyskanie maksymalnego poziomu jednoznaczności wszystkich terminów wchodzących w skład wyrażenia normokształtnego. Dopiero wówczas możliwe jest osiągnięcie finalnego celu wykładni, czyli normy, która

\footnotetext{
${ }^{26}$ A. Choduń, op. cit., s. 114.

${ }^{27}$ Por. M. Zieliński, Wykładnia prawa. Zasady, reguły, wskazówki, Warszawa 2010, s. $251 \mathrm{n}$.

28 Por. ibidem, s. 251-252.

${ }^{29}$ Por. ibidem, rozdz. V.

30 Por. K. Płeszka, Wykładnia rozszerzająca, Warszawa 2010, s. 153 n.
} 
jest pojmowana jako wypowiedź charakteryzująca się maksymalnym poziomem jednoznaczności tworzących ją wyrażeń. W fazie percepcyjnej wykładni norma jako wypowiedź jednoznaczna podlega percepcji (uświadomieniu), pojmowanemu jako ostateczne odczytanie sensu interpretowanego tekstu prawnego ${ }^{31}$.

W fazie percepcyjnej dążeniu do maksymalnej jednoznaczności wypowiedzi, która pretenduje do statusu normy, towarzyszy nakaz osiągnięcia możliwie najwyższego poziomu spójności aksjologicznej tekstu prawnego. Imperatyw ten znajduje wyraz w dyrektywie nakazującej przeprowadzenie wykładni funkcjonalnej nawet w wypadku uzyskania jednoznacznego wyniku wykładni językowej, w celu uzyskania wyższego poziomu zgodności efektu wykładni, czyli normy, z podstawowymi wartościami systemu prawa ${ }^{32}$. Konsekwencją tej dyrektywy jest również przyjęta koncepcja wykładni rozszerzającej i zwężającej. Zgodnie z tą koncepcją wykładnia rozszerzająca lub zwężająca polega na przełamaniu jednoznacznego wyniku wykładni językowej przez zastosowanie dyrektyw funkcjonalnych. Podstawową przesłanką dokonania tak pojmowanej wykładni rozszerzającej lub zwężającej jest sytuacja, w której jednoznaczny wynik wykładni językowej jest nie do pogodzenia z podstawowymi wartościami systemu prawa wyrażonymi w zasadach konstytucyjnych ${ }^{33}$.

Warto zauważyć, że derywacyjna koncepcja wykładni zakłada jakiś wariant semantyki niereferencjalnej, zgodnie z którym znaczeniem wypowiedzi językowej jest inna wypowiedź językowa. Jest tak, ponieważ na gruncie omawianej koncepcji wykładni znaczeniem przepisu jako wypowiedzi niejednoznacznej jest norma jako wypowiedź jednoznaczna. Zwolennicy takiej koncepcji semantyki zmierzają do zbudowania języka opisu semantycznego pojmowanego jako idealnie jednoznaczna struktura językowa, w której można by wyrazić znaczenie wszystkich niejednoznacznych wyrażeń języka potocznego. Inaczej mówiąc, w przypadku przyjęcia semantyki niereferencjalnej mamy do czynienia z próbą tworzenia jednoznacznego metajęzyka, którym można by zastąpić niejednoznaczny język potoczny. Można przyjąć, że w wypadku omawianej koncepcji wykładni język norm jest właśnie przykładem takiego idealnego języka opisu semantycznego, funkcjonującego w charakterze metajęzyka nadbudowanego nad językiem potocznym, w którym sformułowane są przepisy prawne.

Koncepcja derywacyjna bez wątpienia eksponuje optymalizacyjny charakter wykładni prawa. Wykładnia prawa w ujęciu derywacyjnym ma charakter optymalizacyjny, ponieważ jest działaniem poznawczym, które maksymalizuje wartość przedmiotu interpretacji, czyli tekstu prawnego, przez wykazanie, że pod jego niedoskonałą warstwą powierzchniową (przepisy prawne) kryje się doskonała warstwa głęboka (normy prawne). Można zatem powiedzieć, że optymalizacyjny

\footnotetext{
${ }^{31}$ Por. M. Zieliński, Wyktadnia..., s. 343.

32 Por. ibidem, s. 342-343.

${ }^{33}$ Por. K. Płeszka, op. cit., s. 181 n.
} 
charakter wykładni jest przesądzony w wyniku pojęcia prawa, zgodnie z którym prawo ma strukturę dualną, obejmującą przepisy i normy. Punktem wyjścia wykładni jest tekst prawny, postrzegany w jego warstwie powierzchniowej jako chaotyczny, alogiczny i nieuporządkowany zbiór przepisów jako wypowiedzi wieloznacznych. W efekcie wykładni tak postrzegany tekst prawny (albo fragment tego tekstu) jest przedstawiany jako jednoznaczny (zamienny) z zakodowaną w tym tekście idealną strukturą normatywną, którą tworzy uporządkowany systemowo zbiór norm jako wypowiedzi jednoznacznych lub też wypowiedzi wykazujących możliwy do osiągnięcia poziom jednoznaczności. Jak na to wskazywałem, normę lub uporządkowany systemowo zbiór norm, poza jednoznacznością, dodatkowo charakteryzuje wysoki poziom spójności aksjologicznej z podstawowymi wartościami systemu prawa określonymi w konstytucji. W ujęciu derywacyjnym interpretacji prawniczej efekt wykładni zastępuje jej punkt wyjścia, ponieważ są to elementy jednoznaczne, to znaczy ich zawartość treściowa jest taka sama. Efekt wykładni w postaci normy lub uporządkowanego systemowo zbioru norm jest jednak nieporównanie doskonalszą formą wyrażenia treści zakodowanych przez ustawodawcę w postaci przepisów prawnych. Wykładnia jako proces optymalizacyjny ujawnia niedostępny bezpośredniemu postrzeganiu głęboki poziom tekstu prawnego w postaci zakodowanych w tekście jednoznacznych i uporządkowanych systemowo struktur normatywnych. Wartość tekstu jako zbioru przepisów prawnych zostaje zmaksymalizowana przez wykazanie w procesie wykładni, że kryje on uporządkowaną systemowo strukturę jednoznacznych wypowiedzi normatywnych tworzących strukturę głęboką tekstu prawnego. W takim ujęciu warstwa powierzchniowa tekstu prawnego, którą tworzy zbiór przepisów, jest tylko niedoskonałą, jakkolwiek konieczną ze względu na wymogi techniki legislacyjnej, formą zapisu doskonałej struktury normatywnej wykazującej cechy jednoznaczności i systemowego uporządkowania. Ujawnienie tej doskonałej struktury normatywnej jest zadaniem, które interpretator może wykonać, jeśli zastosuje wskazane przez koncepcję derywacyjną zasady, reguły i wskazówki, w określonej przez tę koncepcję kolejności.

W najnowszych ujęciach koncepcji derywacyjnej charakterystyczne jest postrzeganie wykładni w płaszczyźnie epistemologicznej jako swoiście prawniczego procesu poznania tekstu prawnego, który polega na stosowaniu logicznie uporządkowanego zestawu zasad, reguł i wskazówek. Logiczne uporządkowanie oznacza, że nie jest to zbiór przypadkowo zgromadzonych dyrektyw, lecz zestaw zasad, reguł i wskazówek uporządkowanych w ten sposób, że zastosowaniew dyrektywy D1 jest logicznie pierwotnym warunkiem zastosowania dyrektywy D2. Inaczej mówiąc, ujęcie interpretacji prawniczej w płaszczyźnie epistemologicznej zakłada, że wykładnia jako proces poznawczy jest sekwencją logicznie uporządkowanych działań interpretacyjnych. Proces ten dokonuje się przez zastosowanie uporządkowanego relacją pierwotności logicznej zestawu zasad, reguł i wskazówek, które postrzegane są jako dyrektywy heurystyczne, a więc takie, które steru- 
ją procesem dochodzenia do ujawnienia (odsłonięcia) ostatecznego sensu tekstu prawnego zawartego $\mathrm{w}$ jego strukturze głębokiej ${ }^{34}$. W konsekwencji tak pojmowany proces poznawczy jest przedstawiany — przynajmniej w najnowszych ujęciach - jako proces konkluzywny. Oznacza to, że postępując zgodnie z proponowaną procedurą stosowania zasad, reguł i wskazówek, na podstawie danego fragmentu tekstu prawnego jesteśmy w stanie odsłonić zawsze tę samą, spójną i jednoznaczną strukturę normatywną, zakodowaną w tekście prawnym przez prawodawcę ${ }^{35}$.

Warto zauważyć, że pojmowanie procesu wykładni jako mającego charakter poznawczy procesu logicznego zakłada jego znaczną obiektywizację ${ }^{36}$. Jeżeli proces wykładni ma być procesem konkluzywnym, to znaczy takim, w którym poddając interpretacji określony przepis lub zbiór przepisów przez zastosowanie uporządkowanego logicznie zestawu zasad, reguł i wskazówek otrzymujemy zawsze ten sam wynik w postaci normy lub uporządkowanego systemowo zbioru norm, to wówczas musimy przyjąć, że jest to proces w znacznej mierze zobiektywizowany, to znaczy niezależny od przyjęcia subiektywnych postaw oceniających przez podmioty dokonujące wykładni. Istotne jest też to, że odsłonięcie w procesie wykładni idealnej struktury normatywnej w postaci normy lub zbioru norm nie jest aktem jej kreacji w aktywnych aksjologicznie działaniach interpretacyjnych. Struktura głęboka tekstu prawnego jest dana przez prawodawcę w następstwie działań legislacyjnych, które polegają na kodowaniu norm w przepisach, a rolą interpretatora jest jej poznanie (ujawnienie) przez działania, które są w znacznej mierze niezależne od przyjęcia przez podmiot poznający określonej postawy oceniającej.

Zwróćmy też uwagę na swoisty antyfenomenalizm omawianej koncepcji wykładni prawa, który przejawia się $\mathrm{w}$ warstwie założeń zarówno ontologicznych, jak i metodologicznych. Antyfenomenalizm ontologiczny wyraża się w przyjęciu założenia o istnieniu dualistycznej struktury tekstu prawnego. Struktura ta obejmuje: a) dostępną bezpośredniemu postrzeganiu warstwę powierzchniową, którą tworzą przepisy prawne pojmowane jako zdania w sensie gramatycznym występujące $\mathrm{w}$ tekście aktów prawnych, oraz b) niedostępną bezpośredniemu postrzeganiu i w tym sensie ukrytą warstwę głęboką, tworzoną przez zakodowane w tekście normy prawne. Warstwa powierzchniowa (zjawisko) jest przy tym formą przejawiania się warstwy głębokiej (istota). Antyfenomenalizm metodologiczny polega na przyjęciu założenia, że wiedza na temat istoty nie jest prostą sumą wiedzy na temat jej formy przejawiania się, czyli zjawiska. Odnosząc to do koncepcji derywacyjnej, można powiedzieć, że twierdzenia na temat norm nie są przekładalne czy też logicznie równoważne określonej sumie twierdzeń na temat przepisów prawnych. Poznanie normy przez wykładnię tekstu prawnego prowadzi zatem do przyrostu wiedzy, która nie jest redukowalna do prostej sumy wiedzy na temat

\footnotetext{
34 A. Choduń, op. cit., s. 123.

35 Ibidem, s. 124.

${ }^{36}$ Ibidem, s. 123.
} 
przepisów prawnych. Takie stanowisko jest zgodne $\mathrm{z}$ antyfenomenalizmem tak zwanej szkoły poznańskiej, w ramach której prawoznawstwo jest interpretowane przy zastosowaniu idealizacyjnego modelu poznania naukowego ${ }^{37}$.

\section{KONKLUZJE}

W opracowaniu ujmuję wykładnię prawa w perspektywie epistemologicznej jako szczególny typ poznania prawniczego. Postrzegane w tej perspektywie obie scharakteryzowane koncepcje wykładni prawa określają interpretację prawniczą jako sposób poznania prawa, który wykazuje cechy wspólne z poznaniem filozoficznym.

Zarówno twierdzenia filozoficzne, jak i twierdzenia interpretacyjne to wypowiedzi, które nie mają sensu empirycznego, to znaczy nie są empirycznie rozstrzygalne. Oznacza to, że nie można orzekać o ich prawomocności, w szczególności o ich prawdziwości lub fałszywości, odwołując się do kryteriów empirycznych. Twierdzenia filozoficzne, w szczególności o charakterze metafizycznym, na przykład dotyczące celu procesu historycznego, nie mają sensu empirycznego, co oznacza, że nie mogą być weryfikowane lub falsyfikowane przez odwołanie się do doświadczenia, to znaczy do zdań spostrzeżeniowych pojmowanych jako zdania o faktach, sformułowane w terminach obserwacyjnych denotujących bezpośrednio lub pośrednio obserwowalne własności określonych obiektów. Mówiąc nieco inaczej, wobec tego typu twierdzeń nie można wskazać okoliczności, których zaistnienie oznaczałoby ich falsyfikację. Z kolei twierdzenia interpretacyjne typu „Norma N ma znaczenie Z” są podobne do twierdzeń filozoficznych, ponieważ też nie mają sensu empirycznego, jako że nie są to twierdzenia opisowe o faktach, takich jak fakt ustanowienia normy lub stwierdzające obiektywnie istniejące znaczenie normy jako rodzaj jakiegoś faktu normatywnego. Są to wypowiedzi o powinnościach (o prawach i obowiązkach określonych podmiotów) i jako takie mają charakter twierdzeń praktycznych formułowanych $w$ ramach dyskursu prawniczego postrzeganego jako rodzaj dyskursu praktycznego (dyskurs o wartościach i powinnościach). Kryteriami ich prawomocności (akceptacji w dyskursie) są argumenty przyjmowane przez daną wspólnotę interpretacyjną (audytorium) w postaci dyrektyw interpretacyjnych oraz wypowiedzi oceniających. Za Jerzym Wróblewskim można przyjąc następującą formułę twierdzenia interpretacyjnego: „Norma N ma znaczenie Z ze względu na dyrektywy D1, D2..., Dn oraz wartości W1, W2 ...,Wn". Prawomocność tak określonego twierdzenia, rozumiana jako jego akceptowalność przez dane audytorium, jest zrelatywizowana do wartości, ponieważ stosowanie dyrektyw interpretacyjnych najczęściej zakłada konieczność wartościowania. Dlatego prawomocność twierdzeń interpretacyjnych jako twierdzeń praktycznych jest relatywna, czyli względna w sensie podwójnym: 1. ma

${ }^{37}$ L. Nowak, Interpretacja prawnicza, Warszawa 1974, passim. 
charakter lokalny, to znaczy jest ograniczona do danego audytorium prowadzącego dyskurs praktyczny; 2. ma charakter subiektywny w sensie psychologicznym, ponieważ odwołuje się do przekonań czy też przeświadczeń aksjologicznych uczestników dyskursu praktycznego. W konsekwencji, ze względu na poziom uwikłania aksjologicznego, prawomocność twierdzeń filozoficznych i twierdzeń interpretacyjnych ma charakter argumentacyjny. Oznacza to, że przesłankami akceptowalności obu typów twierdzeń nie są przesłanki empiryczne, lecz wyłącznie reguły argumentacji (topiki) wykorzystywane w danym typie dyskursu. W wypadku dyskursu prawniczego przesłankami prawomocności twierdzeń interpretacyjnych są dyrektywy wykładni mające postać postulatów kierowanych pod adresem interpretatora. Ogólnie są to przesłanki o charakterze normatywnym, które w procesie wykładni mogą pełnić funkcję heurystyczną lub uzasadniającą.

Częstym motywem w poznaniu filozoficznym, w szczególności mającym jawnie lub skrycie metafizyczny charakter, jest motyw dualistycznej ontologii, polegający na wyróżnieniu w strukturze bytu dostępnej postrzeganiu, lecz pogrążonej w chaosie warstwy powierzchniowej oraz idealnie zharmonizowanej struktury głębokiej, którą trzeba dopiero ujawnić w procesie interpretacji. Podobnie w interpretacji prawniczej występuje motyw podwójnej struktury prawa w postaci założenia o istnieniu struktury powierzchniowej, którą tworzą teksty prawne postrzegane jako mniej lub bardziej chaotyczne i niejasne zbiory przepisów, oraz struktury głębokiej, tworzonej przez uporządkowane systemowo normy (koncepcje analityczne wykładni Jerzego Wróblewskiego i Macieja Zielińskiego) lub spójne aksjologicznie zasady prawa (hermeneutyczna koncepcja wykładni Ronalda Dworkina).

Zarówno w wypadku poznania filozoficznego, jak i poznania prawniczego mamy do czynienia $\mathrm{z}$ działaniem optymalizacyjnym, polegającym na maksymalizacji wartości przedmiotu interpretacji. W obu optymalizacja polega na wykazaniu, że niedoskonała warstwa powierzchniowa jest formą przejawiania się doskonałej struktury głębokiej przedmiotu interpretacji. W przypadku poznania filozoficznego maksymalizacja wartości przedmiotu interpretacji polega na dowodzeniu, że dostępna postrzeganiu warstwa powierzchniowa bytu jest niedoskonałą formą przejawiania się doskonałego bytu wyższego rzędu, przybierającego postać idealnej wspólnoty, której istnienie ma silne uzasadnienie aksjologiczne. Przykładowo jest to motyw główny w filozofii Platona, Hegla, Marksa czy Habermasa. $Z$ kolei w wypadku interpretacji prawniczej ten sam proces polega na wykazaniu, że tekst prawny jako warstwa powierzchniowa prawa jest formą przejawiania się idealnej struktury normatywnej tworzącej jego strukturę głęboką. W obu interpretacjach poznanie jest aktywnością sensotwórczą, którą można określić jako oswajanie chaosu przez wykazanie, że jest on tylko chaosem pozornym, to znaczy przypadkowym (niekoniecznym), pod którym kryje się konieczny ład i harmonia.

W wypadku klaryfikacyjnej koncepcji wykładni, której Jerzy Wróblewski nadaje charakter opisowy, co oznacza, że proponowana teoria wykładni ma być opisem rzeczywistej praktyki interpretacyjnej, podstawowym założeniem, które 
musi przyjąć interpretator, jest założenie, że prawo jest bytem systemowym powstałym w wyniku działań racjonalnego prawodawcy. Imperatyw postrzegania prawa jako bytu systemowego zakłada tu, że wszelkie luki i sprzeczności w prawie mają charakter pozorny (ustawodawca tylko niefortunnie się wyraził), a nie rzeczywisty, czyli polityczny, związany z realnymi sprzecznościami społecznymi. Zadaniem interpretatora jest usunięcie tych pozornych niedoskonałości występujących na poziomie językowym, a więc powierzchniowym, i ujawnienie głębokiej, ontologicznej systemowości prawa, które z założenia charakteryzuje się jednością teleologiczną, socjologiczną, aksjologiczną, formalną i materialną. Jeżeli interpretując prawo, postrzegamy chaos, to należy przyjąć, że jest to chaos pozorny, to znaczy chaos prima facie i jako taki możliwy do usunięcia w interpretacji.

Odnośnie do koncepcji derywacyjnej wykładni, której Maciej Zieliński nadaje charakter normatywny, przedstawiając ją w postaci zbioru zasad, reguł i wskazówek adresowanych do interpretatora, należy przyjąć, że chaos występuje wyłącznie w warstwie powierzchniowej prawa, to znaczy na poziomie przepisów prawnych. Pod tą warstwą kryje się idealnie uporządkowana struktura norm jako wypowiedzi jednoznacznych, która została zakodowana przez prawodawcę w formie przepisów prawnych. Interpretator musi tę idealną strukturę normatywną odkodować, stosując proponowane przez autora zasady, reguły i wskazówki.

$\mathrm{W}$ omówionych przypadkach optymalizacyjny charakter interpretacji prawniczej jest przesądzony w wyniku przyjętego pojęcia prawa. W pierwszym przypadku prawo jest narzędziem tworzenia bytu wyższego rzędu, jakim jest byt wolny od alienacji. W konsekwencji zadaniem interpretatora jest uczynienie tego narzędzia doskonałym przez ujawnienie głębokiej i ontologicznej systemowości prawa. W drugim przypadku prawo ma strukturę dualną, którą tworzą przepisy i normy prawne. W konsekwencji zadaniem interpretatora jest ujawnienie doskonałej struktury normatywnej przez odkodowanie norm z przepisów prawnych.

\section{LEGAL INTERPRETATION AS AN OPTIMISING ACTIVITY}

\section{Summary}

The purport of the article consists in defending the thesis clearly defined in the title of elaboration, according to which, legal interpretation may be conceived as an optimising activity, because it inevitably aims at maximising the value of the subject of interpretation (legal text). Moreover, I tend to point out that legal interpretation as well as philosophical cognition share a set of common traits such as intuitiveness, by which I mean the lack of opportunities to fully apply inter-subjective empirical criteria of the validity of formulated propositions. Both in the case of legal interpretation and philosophical cognition, interpretation performs an optimising function, by which I understand introducing axiological order into the subject of cognition.

Keywords: legal interpretation, optimising activity, maximisation of the value, legal cognition, philosophical cognition 


\section{BIBLIOGRAFIA}

Chodun A., Maciej Zieliński’s (derivative) concept of legal interpretation, „Studia Prawa Publicznego” 2015, $\mathrm{nr} 2$ (10).

Lang W., Wróblewski J., Zawadzki S., Teoria państwa i prawa, Warszawa 1986.

Nowak L., Interpretacja prawnicza, Warszawa 1974.

Opałek K., Wróblewski J., Prawo, metodologia, filozofia, teoria prawa, Warszawa 1991.

Opałek K., Wróblewski J., Zagadnienia teorii prawa, Warszawa 1969.

Patryas W., Rozważania o normach prawnych, Poznań 2001.

Płeszka K., Wyktadnia rozszerzająca, Warszawa 2010.

Pulka Z., Filozoficzne przesłanki pojmowania systemowości prawa w teorii wyktadni Jerzego Wróblewskiego, [w:] Systemowość prawa, red. Z. Pulka „Przegląd Prawa i Administracji” 104, 2016.

Pulka Z., Przestanki prawomocności decyzji interpretacyjnej w teorii wykładni Jerzego Wróblewskiego, „Przegląd Prawa i Administracji” 100/2, 2015.

Pulka Z., Założenie spójności semantycznej systemu prawa w klaryfikacyjnej teorii wykładni, [w:] Postanalityczna filozofia prawa, red. M. Paździora, „Przegląd Prawa i Administracji” 102, 2015.

Wróblewski J., Decyzja sądowa a koncepcje systemu prawa, „Acta Universitatis Lodziensis. Nauki społeczno-humanistyczne, seria I" 1978, z. 28.

Wróblewski J., Modele systemów norm a system prawa, „Studia Prawno-Ekonomiczne” 1969, nr 2.

Wróblewski J., Obowiąywanie systemowe i granice dogmatycznego podejścia do systemu prawa, „Studia Prawno-Ekonomiczne” 36, 1986.

Wróblewski J., Rozumienie prawa i jego wyktadnia, Wrocław 1990.

Wróblewski J., Sadowe stosowanie prawa, Warszawa 1988.

Wróblewski J., Wartości a decyzja sadowa, Wrocław 1973.

Wróblewski J., Zagadnienie niesprzeczności i zupetności systemu prawa, „Zeszyty Naukowe Uniwersytetu Łódzkiego. Nauki humanistyczno-społeczne, seria I" 1958, z. 9.

Wróblewski J., Zagadnienia teorii wyktadni prawa ludowego, Warszawa 1959.

Wróblewski J., Zwroty stosunkowe - wypowiedzi o zgodności z norma, „Zeszyty Naukowe Uniwersytetu Łódzkiego. Nauki humanistyczno-społeczne, seria I" 1969, nr 62.

Zieliński M., Interpretacja jako proces dekodowania tekstu prawnego, Poznań 1972.

Zieliński M., Wykładnia prawa. Zasady, reguły, wskazówki, Warszawa 2010. 